\title{
Haitian/Vilokan Idealism, Phenomenological Structuralism, and the Resolution of the Structure/ Agency Problematic of the Social Sciences
}

\section{Paul C Mocombe* \\ The Mocombeian Foundation, West Virginia State University, USA}

Submission: August 31, 2018; Published: September 20, 2018

*Corresponding author: Paul C Mocombe, The Mocombeian Foundation, West Virginia State University, USA, Email: pmocombe@mocombeian.com

\begin{abstract}
The demystification of the Vodou religion or ontology as practiced in Haiti, epistemologically, reveals a form of transcendental idealism and realism, Haitian/Vilokan Idealism, which produces a hermeneutical phenomenology, materialism, and an antidialectical process to history enframed by a reciprocal justice as its normative ethics. The latter is constantly being invoked by individual social actors to reconcile the noumenal (sacred-ideational) and phenomenal (profane-material) subjective world to maintain balance and harmony between the two so that human actors can live freely and happy in a material resource framework where they are the masters of their own existence without masters or owners of production. In this work, I conclude that a theory and methodology, phenomenological structuralism, can be deduced from the ontology, epistemology, and sociology of Vodou to resolve the structure/agency problematic of the social sciences.
\end{abstract}

Keywords: Haitian/Vilokan Idealism; Vodou Ethic and the Spirit of Communism; Religiosity; Haitian Epistemology; Vodou; Anti-dialectical

\section{Background of the Problem}

The linguistic turn in meaning and identity constitution, whether in linguistics or the social sciences, presupposes that meaning and the nature of human identity or consciousness are nothing more than the relationships which pertain within a given linguistic system, structure, culture, or social structure. Thus, such questions as those pertaining to matters of human agency, individual or shared interests, community, etc., have generally been ignored by so-called "structuralists". This in turn makes most structural approaches synchronic; that is, most structuralists approach a phenomenon at a single moment in history, or as something existing outside history, which is unchanging. It is well known that Ferdinand de Saussure in linguistics, to Claude Lévi-Strauss in anthropology, and Talcott Parsons and Louis Althusser in sociology postulate this synchronic world ordered into an interconnected semiotic system. In Saussurean structuralism, which serves as the model for the social sciences, language "is viewed as a purely arbitrary system of signs in which parole or speech is subsidiary to langue, the formal dimension of language. Parole is the world's messiness that the semiotic order [or formal dimension] shuns", subjecting social actors to its binary rules that gives them their conceptual framework, rather than the other way around.

In anthropology, Lévi-Strauss extends this idea to culture, and culture too becomes a system of external signs, which reflect the structure or categories of the mind, exercised in social relations to order experience. Just the same, in sociology Talcott Parsons employs the notion of structure or system to refer to modern capitalist society as an "organic" whole or totality consisting of interrelated parts (i.e., structurally differentiated) that perform specific functions in relation to each other and contribute to the maintenance of the whole, i.e., structural functionalism. The structural Marxism of Louis Althusser, and many others, replaces both Parsons's conservative holism and Levi-Strauss's mental categories by positions in modes of production and relations to the means of production for the structure or system that governs meaning and gives social actors their conceptual framework [1].

The logical consequence of the adoption of the Saussurean position by Lévi-Strauss, Parsons, and Althusser in philosophy and the social sciences, however, is the implication that human action, or consciousness, lies in the reproduction of the relational (binary rules for inclusion and exclusion) objective models of society as either structured by our minds, or the external interrelated structures of signification as internalized by social actors. Therefore, to understand human social agency, one only needs to understand either how the mind structures reality (transcendental idealism), or the differentiating rules of a culture, social structure, or social system. Both positions, however, are problematic. In the psychologism of the former case, social structure reflecting the structure of the mind, social practice or action and its variability are inconceivable in that there is no analytical means to explain how the internal "binary" processes of the mind give rise to the external 
empirical phenomena of social structures, practices, and their variabilities. In the latter case, structure or social structure as a reflection of the internalization of external functional structures of signification, i.e., part/whole relationship, the possibility for, and the origins of, the variability of practices, which have ontological status in the world, amongst irreducibly situated subjects are inconceivable, as human subjects or social actors are only reproducing in their actions the relational meaning and representation of the external objective social world (society), without any alternative practices, deviations, or improvisations outside of the structural differentiation of the social structure.

Moreover, since the 1960's with the advent of postmodern and post-structural theories into the theoretical discourses of social science academics a new struggle regarding the origins and nature of identity and consciousness vis-à-vis the aforementioned problematics has dominated social science and philosophical theories. The issue centers on several factors raised by postmodern and post-structural thinkers in the likes of Michel Foucault, Jacques Derrida, and Jacques Lacan against the structuralism of the sciences,

a. They question the validity regarding the Cartesian rational individual, which Foucault and Derrida deny in favor of their attempt to dissolve the subject altogether.

b. They question the interdependency of the constitution of a stable structure and a distinct subject with agency, in denying the latter they undermine the former.

c. They question the status of science.

d. Finally, they question the possibility of the objectivity of any language of description or analysis. Although these factors raised in the writings of Jacques Lacan, Jacques Derrida, and Michel Foucault are theoretically legitimate and have posed tremendous problems for the social sciences and their constitution as a science based on the notion of a stable structure constituted by stable subjects with agency. These problems have not adequately been addressed by Marxist social theorists in the likes of Louis Althusser, Pierre Bourdieu, Jürgen Habermas, Anthony Giddens, and Marshall Sahlins working to resolve these issues by attempting to synthesize the rationality of the individual with the phenomenological discourses of the former theorists, and Marxist and structural Marxist philosophy.

Hence the structure/agency debate in the social sciences emphasize the rational origins of the reproduced and transformed social actions of social actors that constitute a social structure: are social actors determined and driven by internal invariable structures of the mind, or are social actors' automatons determined and driven by external relational structures of signification [1]? Thus, in the social scientific form of the debate, biological determinism, i.e., innate senses of anything, as well as the Lévi-Straussian sense, i.e., innate structure of the mind, were out rightly rejected. Also, the idea that social actors are irreducibly situated subjects who act and react based on rational calculations as they respond to external social processes (social structure) or stimuli was for the most part dismissed. Total rationality was viewed as an impossibility given the inability of social actors to either know all the choices available to them in the present or know the complete future outcomes of those choices. This made rationality necessarily relative to a frame of reference or structure of signification, which rejects the indeterminacy of meaning and decentered subject of postmodern/post-structural theorizing.

Hence, the focus in the study of action and interaction in the social sciences was thus not a matter of denying or minimizing the rational potential of social actors, but expressed rather an urgent need to understand where 'the system' or structure that limits their knowledge and stabilizes society "comes from-how it is produced and reproduced, and how it may have changed in the past or be changed in the future" [2]. In other words, thinkers plagued by this debate, sought "to explain the relationship(s) that obtain between human action, on the one hand, and some global entity which we may call the system, [or social structure, structure, or culture] on the other" [2], when the latter (i.e., the system) is not a necessary reflection of neither biology, nor the structure of the mind, but an external force of rules of conduct, i.e., categorical boundaries, that stabilizes society and thereby constitute the identity of social actors as argued by Talcott Parsons and Louis Althusser.

From roughly 1975 to the present, an enormous strand of critical writings, expounding a great many strands of theoretical schools of thought, combined to challenge this post-World War II structuralist matrix which denied alternative agencies, outside the relational logic of a structure, system, or culture to social actors. Some were advanced by rationalist thinkers seeking to preserve the idea of individuals as solitary thinkers who act in a purposive rational way, while others were offered by theorists dedicated to preserving the tenets of structural-functionalism and structural-Marxism while explicating the functional role of difference or the variability of practices amongst social actors within social structure not as an invariable by-product of the mind but as an external unified structure of signification or system. Considering this action-oriented response to account for the different provinces of meaning within systems or structures of signification, the term praxis or structurationist theorists will serve as the dominant label for the arguments expounded in opposition to Parsonian structural-functionalism and variants of structural Marxism by prominent theorists such as Pierre Bourdieu, Marshall Sahlins, Anthony Giddens, and Jürgen Habermas [2,3]. These arguments are complex, and to examine them together is necessarily to do violence to the purity of notions advanced separately by various authors. The exercise is nevertheless useful at least for revealing their main and common objective, i.e., to resolve the structure/agency debate of the social sciences. 


\section{Global Journal of Archaeology \& Anthropology}

\section{The Structurationist Response and its Problems}

Structural-functionalists and Structural-Marxists in attempting to understand social action (i.e., praxis) within social structures of signification privilege social relations and reproduction via linguistic and symbolic representation over biological determining elements (i.e., race, sex, etc.), for meaning, human action, and consciousness constructions. In doing so, however, they fail to account for the origins and nature of the different provinces of meaning, human action, and consciousness existing within, but at the same time, outside the relational or dialectical prescribed logic of the social structure (structural reproduction and differentiation). Neo-structuralists or structurationists in the like of Pierre Bourdieu with his theory of practice (habitus or constructivist structuralism), Marshall Sahlins through mythopraxis, Anthony Giddens [4] through his theory of structuration, and Jürgen Habermas [5,6] with his theory of "communicative action," however, attempt to do just that, "explain the relationship(s) that obtain between human action, on the one hand, and some global entity which we may call the system, [or social structure, structure, or culture] on the other" in order to capture the nature of social action, reproduction, transformation, and differentiation within structures of signification. They attempt to do so, for the most part, through "the central notion of the 'duality of structure' which refers to 'the essential recursiveness of social life, as constituted in social practices: structure is both medium and outcome of the reproduction of practices'”.

That is, structures are not only external to social actors, but are internal rules and resources ("form of consciousness") produced and reproduced by actors "unconsciously" (intuitively) in their practices. From this perspective, accordingly, structure, i.e., culture or, sociological speaking, social structure, "may set conditions to the historical process, but it is dissolved and reformulated in material practice, so that history becomes the realization, in the form of society, of the actual [(embodied rules)] resources people put into play". In this understanding, the structure is not an epiphenomenon of the structure of the mind but is a result of the internalization by social actors of external (social structural) rules of conduct which are sanctioned, recursively (re) organized, reproduced, and differentiated in material practice. Thus, social structure, human action, meaning, and consciousness are mutually constituted and united together as "practical consciousness," i.e., a duality.

Ostensibly, like structuralism, structural functionalism, and structural Marxism, the structurationist response to account for the nature of human action within structures of signification, however, is also problematic. That is, the central notion of the duality of structure prevents praxis theorists from accounting for the origins and relational nature of the variability of praxis or "practical consciousnesses" within a structure of signification. The part/whole dialectic of the "duality" concept cannot account for the origins of alternative "practical consciousnesses" that arises because of a. The drives and sensibilities of the body and brain.

b. The drives and impulses, phenomenal properties, of embodied recycled subatomic particles.

c. The deferment of meaning in ego-centered communicative discourse during the internalization process as suggested by postmodern and post-structural theory. Structurationists are only able to account for the dialectic of.

d. structural reproduction and differentiation stemming from the means and mode of production of a society. In this work, building on Haitian metaphysics, epistemology, and sociology, I offer an alternative solution, phenomenological structuralism, to the structure/agency problematic.

\section{Haitian Metaphysics and Epistemology: Haitian/ Vilokan Idealism}

The Haitian epistemological position, Haitian/Vilokan Idealism, that would emerge out of Haitian Vodou is a strong form of Kantian transcendental idealism and realism, which would be institutionalized throughout the provinces and mountains of the island [7-10]. Haitian/Vilokan Idealism is phenomenological, material, and antidialectical in the sense that the emphasis is on the things (concepts, ideas, ideals) of consciousness as revealed to, and interpreted by, human individuals (via the form of sensibility and understanding) from the noumenal world of Vilokan, a parallel mirror world of the phenomenal world where its concepts, ideas, and ideals exist in their purest Platonic form. These things (concepts, ideas, and ideals) of consciousness they in-turn recursively reorganize and reproduce as their practical consciousness antidialectically against the interpretive practical consciousnesses of others within a normative ethic of reciprocal justice of the socioeconomic/political structure of the Lakou as organized in a material resource framework. The lakou is a community of people and houses organized and gathered around a common yard under the directions of an oungan (Vodou priest), manbo (Vodou priestess), or family elder that promoted and promotes a libertarian and egalitarian existence rooted in the Vodou religion and ancestor worship, land ownership arrangements, and working the soil.

Within the lakou system, each individual or nuclear family owned/own their own land, through which they provided/ provide for necessities by growing food and raising livestock for their own consumption and for sale in local markets. They also grew and grow export crops, such as coffee, to buy imported consumer goods such as clothes and tools. The lakou thus divided power in a way that allowed rural residents to live and work as they wished (through land and garden ownership to provide for their own subsistence), while preventing the consolidation of wealth, and therefore control and inhibitor of equality, in the hands of any one person within the community through a set of customs and secret societies of the Vodou religion that regulate(d) land ownership, land transfers, family relationships, and community affairs. Communal assistance and 
exchange, via food sharing, harvesting, house building, religious life, and ancestral worship, under the leadership of women also characterized and characterizes lakou life. The purpose of lakou life is to promote total liberty and equality, via land ownership and self-sufficiency, for all without distinctions and economic differentiation. It is out of the Vodou Ethic (the form of social integration) that the lakou system would emerge as its form of system integration $[11,12]$.

The evolution and rationalization of the phenomenology, materialism, and antidialectics of Haitian/Vilokan Idealism becomes institutionalized and reified via its form of system and social integration called the Lakou and the Vodou Ethic and the spirit of communism, respectively, where human actors can exercise their practical consciousness as they understand them from the noumenal (Vilokanic) world. So unlike the antidialectic of Nietzsche which promotes an existential phenomenology against system and social integration, i.e., the dialectics and holism of Hegel, the antidialectics of Haitian/Vilokan idealism, via its Lakou system promotes a social phenomenology wherein individuals, depending on their spiritual court [1315], intellectual capacity, developmental stage, etc., attempt to constitute their existence based on their understanding of the concepts of the noumenal world (the world of Vilokan) in order to maintain balance and harmony between nature, the individual, and their social interactions as they provide for their material well-being via agricultural production and trade. Difference or freedom of expression and egalitarianism become the contents of their form of system and social integration so that Being, or human existential existence can achieve perfection, embodying the concepts of the noumenal world, and harmony over sixteen life-cycles.

Be that as it may, unlike German Idealism whose intellectual development from Kant to Schopenhauer, Hegel, Marx, Nietzsche, Husserl, Heidegger, and the Frankfurt school produced the dialectic, Marxist materialism, Nietzscheian antidialectics, phenomenology, and deontological ethics; Haitian Idealism, as defined, produces phenomenology, materialism, and an antidialectical process to history enframed by a reciprocal justice as its normative ethics, which is constantly being invoked by individual social actors to reconcile the noumenal (sacredideational) and phenomenal (profane-material) subjective world in order to maintain balance and harmony between the two so that the human actor can live freely and happy with all of being without distinctions or masters. As such, Haitian epistemology as a form of transcendental realism and idealism is phenomenological, in the Heideggerian sense (i.e., hermeneutical), material in the Marxist sense, and antidialectical. It refutes Hegel's claims for the importance of historical formations and other people to the development of self-consciousness. Instead, Haitian/Vilokan idealism emphasizes the things in the consciousness (lwa or concepts, ideas, ideals) of the individual as they stem from the noumenal/Vilokan world, and get bastardize and differentiated according to their level of learning, development, capacity for knowledge, and modality, i.e., the way they know more profoundly-kinesthetically, visually, etc., as they antidialectically seek to reproduce them in the phenomenal world as their practical consciousness against other interpretive formations in the material world.

\section{Phenomenological Structuralism}

Thus, what does Haitian/Vilokan Idealism, its metaphysics, phenomenology, materialism, antidialectics, and reciprocal justice, has to say to modern science, both physical and social, in terms of the development of a theory and methodology. As far as I am concerned it is the materialist holism and metaphysics of Haitian idealism, which attempts to connect cosmology, cosmogony, social relations, the phenomenology of subjective experience, and the process of antidialectics, which is important. For they offer a new conception of human agency, which is tied to physics, phenomenology, and human social relations, that is relevant for the social sciences and its ongoing debate to resolve its structure/agency problematic [16,17]. That is, Haitian idealism is tied to a materialist holism that directs human social action, via its antidialectical historical process, towards the transcendentally real ideational concepts, lwa yo, of the natural and supernatural world above social constructive identifications, which, as subjective positions, attempt to limit human phenomenological agency as it experiences being-in-theworld. In this vision, it offers, through the concept and process of antidialectics and phenomenology, an agential theory of social action that is relevant for the construction of a social theory and methodology for the social sciences against structuralism and structurationism.

It is the metaphysics of Haitian/Vilokam idealism (which parallels membrane theory), its phenomenology, materialism, and antidialectic viewpoint of Haitian social practice, which I tie to the phenomenology of German idealism that it parallels that is important for resolving the structure/agency problematic. Theoretically speaking, in other words, phenomenological structuralism, synthesizes Merleau-Ponty's and Heidegger's phenomenology, with Haitian idealism and phenomenology, Karl Marx's materialism, Althusser's structural Marxism, and Ludwig Wittgenstein's language game to suggest that being-inthe-world with others, our practical consciousness, is a product of our acceptance or antidialectical rejection of the symbols of signification, social class language game, of those bodies in institutional/ideological power positions who control via their bodies (practical consciousness), language, ideologies, ideological apparatuses, and communicative discourse the economic conditions (mode of production) of a material resource framework as we encounter them and their symbols/ signifiers in institutions or ideological apparatuses via our own transcendental ego, bodies, language, and communicative discourse.

Hence, we never experience the things-in-themselves of the world culturally and historically in consciousness. We 
experience them structurally or relationally, "the structure of the conjuncture" (Marshall Sahlins's term) of the mode of production, and our stances/analytics, ready-to-hand, unready-to-hand, present-at-hand, vis-à-vis these ideological structures as they stand in relation to the drives (forms of sensibilities and understanding) of our bodies/brains, impulses of subatomic particles, and the ability to defer meaning in egocentered communicative discourse, determine our practical consciousness or behaviors we recursively organize and reproduce in the material resource framework. So, I reject the ability to know noumena, as posited by Haitian Idealism, via divinations, revelations, intuitions, etc., because of ideology, which requires the human agent and their viewpoint, gaze, or disposition to change to access it.

"Presence-at-Hand," "Readiness-to-Hand," and "UnReadiness-to-Hand,"

We initially know, experience, and utilize the things of the world in the preontological ready-to-hand mode, which is structural and relational. That is, our bodies (nanm in Haitian Idealism) encounter, know, experience, and utilize the things of the world in consciousness, intersubjectively, via their representation as objects of knowledge, truth, usage, and experience enframed and defined in the relational logic and practices or language game (Wittgenstein's term) of the institutions or ideological apparatuses of the other beingsof-the-material resource framework whose historicity comes before our own and gets reified in and as language, ideology, ideological apparatuses, communicative discourse, and social action stemming from the mode of production (i.e., how they organize and distribute the resources of the material resource framework) [18-20]. This is the predefined phenomenal structural, i.e., ontological, world we and our bodies are thrown-in in coming to be-in-the-world. How an embodiedhermeneutically-structured Being as such solipsistically view, experience, understand, and utilize the predefined objects of knowledge, truth, and experienced defined by others and their conditions of possibilities in consciousness to formulate their practical consciousness is albeit indeterminate.

Martin Heidegger is accurate, however, in suggesting that three stances or modes of encounter (Analytic of Dasein), "presence-at-hand," "readiness-to-hand," and "un-readiness-tohand," characterizes our views of the things of consciousness represented intersubjectively via bodies, language, ideology, and communicative discourse, and subsequently determine our practical consciousness or social agency. In "ready-tohand," which is the preontological mode of human existence/ consciousness thrown in the world, we accept and use the things in consciousness with no conscious experience of them, i.e., without thinking about them or giving them, any meaning or signification outside of their intended usage. Heidegger's example is that of using a hammer in hammering. We use a hammer without thinking about it or giving it any other condition of possibility outside of its intended usage as defined by those whose historicity presupposes our own. In "presentat-hand," which, according to Heidegger, is the stance of science (and ideology for me), we objectify the things of consciousness and attempt to determine and reify their meanings, usage, and conditions of possibilities. Hence the hammer is intended for hammering by those who created it as a thing solely meant as such.

The "unready-to-hand" outlook is assumed when something goes wrong in our usage of a thing of consciousness as defined and determined by those who adopt a "present-at-hand" view. As in the case of the hammer, the unready-to-hand view is assumed when the hammer breaks and we must objectify it, by then assuming a present-at-hand position and think about it to either reconstitute it as a hammer or give it another condition of possibility. Any other condition of possibility that we give the hammer outside of its initial condition of possibility which presupposed our historicity becomes relational, defined in relation to any of its other conditions of possibilities it may have been given by others we exist in the world with [21-24]. Hence for Heidegger, the ontological status of being-in-the-world-withothers, via these three stances or modes of encountering the objects of consciousness hermeneutically reveal, through our view, experience, understanding, and usage of the predefined objects of knowledge, truth, and experience.

Whereas Heidegger in his phenomenological work goes on to deal with the existential themes of anxiety, alienation, death, despair, etc. in my phenomenological stance regarding societal constitution or Beings-as-such's-being-in-the-world-withothers via our stances to the body, language, ideology, ideological apparatuses, communicative discourse, and social relations of production, I am not concerned with the phenomenological preoccupation of individual solipsistic existence as defined in Jean-Paul Sartre's work who claims to take off from Heidegger. Instead, I am interested in the universal ontological structure, i.e., social structure or societal constitution and practical consciousness, which arise out of Heidegger's three stances vis-à-vis embodiment, language, ideology, ideological apparatuses, communicative discourse, and social relations of production, which prevents Being from relating their existence to the noumenal world, which is possible as suggested in Haitian Idealism.

Thatis, I am not concerned with Sartre's phenomenologization of the Cartesian res cogitans/ transcendental ego, i.e., the present-at-hand transcendental ego, which he gives ontological status in the world as a solipsistic individual seeking to define themselves for themselves lest they be declared living in bad faith. In my view, the overemphasis of that aspect of Dasein or Being is a product of a specific historical and relational mode of production, and only accounts for one of its analytics as highlighted by Heidegger. For me, the transcendental ego, nanm in Haitian/Vilokan Idealism, which is a part of a universal élan vital, a five-dimensional superverse and four-dimensional multiverse bubbles, existing in another dimension at the 
subatomic particle level, does not, initially, originate out of the historical material world, but several variations of it becomes objectified via embodiment and the aforementioned stances in a universe, galaxy, and historical material world structured, via mode of production, language, ideology, ideological apparatuses, and communicative discourse by other embodied Beings and their stances.

Upon death its historicity via subatomic neuronal particles (and their properties) gets reabsorbed into the élan vital, panpsychic field of the superverse and multiverse, to be recycled to produce future beings. As such consciousness, i.e., practical consciousness, is a product of the stances of Dasein (Martin Heidegger's term) or the human being vis-à-vis the structures of

a. Its embodied recycled past consciousnesses via the microtubules of neurons.

b. The (chemical, biological, physiological) drives and sensibilities of the aggregated body and brain.

c. Language and ideology, which can be deferred in egocentered communicative discourse.

d. Structural reproduction and differentiation resulting from the social relations of production. Be that as it may, as with Heidegger, who refutes Sartre's existential rendering of his phenomenological ontology, I am interested in the objectified societal constitution and practical consciousnesses of the transcendental egos and their relations that emerge within a dominant constitution of Being that controls a material resource framework of the world via bodies, mode of production, language, ideology, ideological apparatuses, and communicative discourse vis-à-vis the stances of the transcendental ego, which if they are truly to be free, ought to assume the antidialectical unfolding highlighted in Haitian/Vilokan Idealism (because the individual is allowed to plot their own land and be self-sufficient) over the dialectical one of its German counterpart.

The individual being is initially constituted as recycled and embodied subatomic particles of the multiverse, which have their own predetermined form of understanding and cognition [25-28], phenomenal properties, based on previous experiences as aggregated matter (this is akin to what the Greek philosopher Plato refers to when he posits knowledge as recollection of the Soul and reincarnation to achieve perfection as highlighted in Haitian Idealism). Again, the individual's actions are not necessarily determined by the embodiment and drives of these recycled subatomic particles. It is an individual's stance, readyto-hand, unready-to-hand, and present-at-hand, when the subatomic particles become aggregated matter or embodied, which determines whether are not they become aware, present-at-hand, of the subatomic particle drives and choose to recursively reorganize and reproduce the content of the drives as their practical consciousness.

This desire to reproduce the cognition and understanding phenomenal properties, of the drives of the recycled subatomic particles, however, may be limited by the structuring structure of the aggregated body and brain of the individual subject. The second origins and basis of an individual's actions are the structuring drives and desires, for food, clothing, shelter, social interaction, and sex, of the aggregated body and brain, which the subatomic particles constitute and embody. In other words, the aggregated body and brain is preprogrammed with its own (biological) forms of sensibility, understanding, and cognition, structuring structure, by which it experiences being-in-theworld as aggregated embodied subatomic particles. These bodily forms of sensibility, understanding, and cognition, such as the drive and desire for food, clothing, shelter, social interaction, linguistic communication, and sex, are tied to the material embodiment and survival of the embodied individual actor, and may or may not supersede or conflict with the desire and drive of an individual to recursively (re) organize and reproduce the structuring structure of the recycled subatomic particles. If these two initial structuring structures are in conflict, the individual moves from the ready-to-hand to the unready-to-hand stance or analytics where they may begin to reflect upon and question their being-in-the-world prior to acting. Hence just as in the case of the structuring structure of the subatomic particles it is an individual being's analytics vis-à-vis the drives of its body and brain in relation to the impulses of the subatomic particles, which determines whether or not they become driven by the desire to solely fulfill the material needs of their body and brain at the expense of the drives/desires of the subatomic particles or the social class language game of the material resource framework they find their existence unfolding in.

The social class language game, and its differentiating effects, an individual find their existence unfolding in is the third structuring structure, which attempts to determine the actions of individual beings as they experience being-in-the-world as embodied subatomic particles. The aggregated individual finds themselves objectified and unfolding within a material resource framework controlled by the actions of other bodies, which presuppose their existence, via the actions of their bodies (practical consciousness), language, communicative discourse, ideology, and ideological apparatuses stemming from how they satisfy the desires of their bodies and subatomic particle drives (means and mode of production). What is aggregated and reified as a social class language game by those in power positions via and within its praxis, language, ideology, ideological apparatuses, and communicative discourse attempts to interpellated and subjectify other beings to its interpretive frame of satisfying their bodily needs, fulfilling the impulses of their subatomic particles, and organizing a material resource framework at the expense of all others, and becomes a third form of structuring individual action based on the mode of production and how it differentiates individual actors.

An individual's interpellation, subjectification, and differentiation within the social class language game that presupposes their being-in-the-world attempts to determine 
their actions or practical consciousness via the reified language, ideology, etc., of the social class language game, the meaning of which can be deferred via the communicative discourse of the individual actors. Hence, the deferment of meaning in egocentered communicative discourse of the language and ideology of a social class language game is the final means of determining an individual's action or practical consciousness outside of, and in relation to, its stance, i.e., analytics, vis-à-vis the drives of subatomic particles, desires of the body and brain, and structural reproduction and differentiation.

Whereas the practical consciousness of the transcendental ego stemming from the impulses of embodied subatomic particles are indeterminant as with its neuronal processes involved with the constitution of meaning in ego-centered communicative discourse (Albeit physicists are in the process of exploring the nature, origins, and final states of subatomic particles, and neuroscientists are attempting to understand the role of neuronal activities in developing the transcendental ego and whether or not it continues to exist after death). The form of the understandings and sensibilities of the body and brain are determinant as with structural reproduction and differentiation of the mode of production, and therefore can be mapped out by neuroscientists, biologists, and sociologists to determine the nature, origins, and directions of societal constitution and an individual actor's practical consciousness.

The interaction of all four elements in relation to, or mediated by, the stance of the transcendental ego of the individual actor are the basis for human actions in the world. In the end, consequently, most of the practical consciousness will be a product of an individual actor's embodiment and the structural reproduction and differentiation of a social class language game given:

a. The determinant nature of embodiment, form of understanding and sensibility of the body and brain amidst, paradoxically, the indeterminacy of impulses, phenomenal properties, of embodied subatomic particles and the neuronal processes involved in ego-centered communicative discourse.

b. The consolidation of power of those who control the material resource framework wherein a society, the social class language game, is ensconced and the threat that power (consolidated and constituted via the actions of bodies, mode of production, language, ideology, ideological apparatuses, and communicative discourse) poses to the ontological security of an aggregated individual actor who chooses, dialectically, (or not by assuming an antidialectical position) either ready-to-hand or present-at-hand to recursively reorganize and reproduce the ideals of the society as their practical consciousness. Those who seek to antidialectically maintain their subjective positions do so at the constant threat to their ontological security.

\section{References}

1. Althusser Louis (2001) Lenin and Philosophy and Other Essays. Monthly Review Press, New York, USA.
2. Ortner Sherry (1984) Theory in Anthropology Since the Sixties. Comparative Studies in Society and History 26: 126-166.

3. Crothers Charles (2003) Technical Advances in General Sociological Theory: The Potential Contribution of Post-Structurationist sociology. Perspectives 26(3): 3-6.

4. Giddens Anthony (1984) The Constitution of Society: Outline of the Theory of Structuration. Polity Press, Cambridge, UK.

5. Habermas Jürgen (1987) The Theory of Communicative Action: Lifeworld and System: A Critique of Functionalist Reason. Beacon Press, Boston, USA.

6. Habermas Jürgen (1984) The Theory of Communicative Action: Reason and the Rationalization of Society Beacon Press, Boston, USA.

7. Mocombe Paul C (2016) The Vodou Ethic and the Spirit of Communism: The Practical Consciousness of the African People of Haiti. University Press of America, Maryland, USA.

8. Buck-Morss, Susan (2009) Hegel, Haiti, and Universal History. University of Pittsburgh Press, Pittsburgh, USA.

9. Cohen J (2002) Protestantism and Capitalism: The Mechanisms of Influence. Aldine de Gruyter, New York, USA.

10. Du Bois Laurent (2004) Avengers of the New World. Harvard University Press, Massachusetts, USA.

11. Fanon Frantz (1967) Black Skin, White Masks (Charles Lam Markmann, Trans.). Grove Press, New York, USA.

12. Fraser Nancy (1997) Justice Interruptus: Critical Reflections on the "Postsocialist" Condition. Routledge, New York \& London, UK.

13. Gartman David (2002) Bourdieu's Theory of Cultural Change: Explication, Application, Critique. Sociological Theory 20(2): 255-277.

14. Gutman Herbert (1976) The Black Family in Slavery and Freedom 1750-1925. Pantheon Books, New York, USA.

15. Holloway Joseph E (1990) Africanisms in American Culture. Bloomington and Indianapolis: Indiana University Press, Indiana.

16. Holloway, Joseph E (1990) The Origins of African-American Culture. In Joseph Holloway (Eds.), Africanisms in American Culture Bloomington and Indianapolis: Indiana University Press, Indiana, p. 19-33.

17. Hudson, Kenneth, Andrea Coukos (2005) The Dark Side of the Protestant Ethic: A Comparative Analysis of Welfare Reform. Sociological Theory 23(1): 1-24.

18. James CLR (1986) The Black Jacobins: Toussaint L' Ouverture and the San Domingo Revolution. Vintage, USA.

19. Karenga Maulana (1993) Introduction to Black Studies. The University of Sankore Press, California, USA.

20. Lukács Georg (1971) History and Class Consciousness: Studies in Marxist Dialectics (Rodney Livingstone, Trans.). Cambridge, The MIT Press, Massachusetts, USA.

21. Lukács Georg (2000) A Defence of History and Class Consciousness: Tailism and the Dialectic (Esther Leslie, Trans.). Verso, London and New York, UK.

22. Marx Karl (1992) Capital: A Critique of Political Economy (Volume 1, Samuel Moore and Edward Aveling, Trans.). International Publishers, New York, USA.

23. Marx Karl (1998) The German Ideology. New York: Prometheus Books. Mocombe, Paul C. The Soul-less Souls of Black Folk: A Sociological Reconsideration of Black Consciousness as Du Boisian Double Consciousness. University Press of America, Maryland, USA.

24. Patterson Orlando (1982) Slavery and Social Death: A Comparative Study. Cambridge, Harvard University Press, Massachusetts, USA. 
25. Ramsey Kate (2011) The Spirits and the Law: Vodou and Power in Haiti. University of Chicago Press, Chicago, USA.

26. Rubin Vera (1960) Caribbean Studies: A Symposium. Seattle: University of Washington Press, USA.

27. Smith MG (1960) The African Heritage in the Caribbean. In Vera
Rubin (Eds.), Caribbean Studies: A Symposium Seattle: University of Washington Press, USA, p. 34-46.

28. Weber Max (1958) The Protestant Ethic and the Spirit of Capitalism (Talcott Parsons, Trans.). Charles Scribner's Sons, New York, USA.

\section{Your next submission with Juniper Publishers} will reach you the below assets

- Quality Editorial service

- Swift Peer Review

- Reprints availability

- E-prints Service

- Manuscript Podcast for convenient understanding

- Global attainment for your research

- Manuscript accessibility in different formats ( Pdf, E-pub, Full Text, Audio)

- Unceasing customer service

Track the below URL for one-step submission https://juniperpublishers.com/online-submission.php 